\title{
PROTECTIVE ACTIVITY OF NORMAL HUMAN AND ANIMAL SERA FOR SULFAPYRIDINE-TREATED MICE INFECTED WITH PNEUMOCOCCI
}

\author{
BY SOPHIE SPICER \\ (From The Research Laboratories of The Department of Health, New York City)
}

(Received for publication February 10, 1942)

With the belief that the therapeutic activity of sulfonamide drugs in pneumococcic infections depends in part on the presence of protective mechanisms other than the bacteriostasis produced by the drugs, a knowledge of the enhancement offered by normal serum is needed to clarify the mechanisms of this therapeutic action. The purpose of the present communication is to present experiments which deal with the activity of normal animal and human sera in enhancing the antipneumococcic action of sulfapyridine. Normal mouse, rabbit, guinea pig, rat, dog, infant human, and adult human sera were examined, with white mice used as test animals.

\section{MATERIAL AND METHODS}

The test to determine the enhancement of mouse protection produced by each serum consisted of the inoculation of graded doses of pneumococci to three series of mice, one series receiving serum alone, one series receiving sulfapyridine, and one series receiving both serum and sulfapyridine.

The sulfapyridine was administered orally, mixed with the food. The food used was ordinary mouse biscuits, ground in a meat grinder and sifted through a fine sieve. The resulting powder was thoroughly mixed with sulfapyridine in the proportion of one part of the drug to ninety-nine parts of the powdered food, giving a one per cent sulfapyridine content. The mice were housed 6 in a cage, and the powdered food, with the sulfapyridine, given in open boxes, so that they had free access to it.

The maximum protection with sulfapyridine alone resulted from its administration for from 3 to 6 days. There was approximately 33 per cent survival for Type I and survival varied from 20 per cent through 80 per cent with strains of Type III pneumococci. However, only 2-day sulfapyridine treatment was used in enhancement tests because comparisons were most clear cut with sulfapyridine dosage of this duration.

The virulence of the cultures was such that $10^{-8} \mathrm{ml}$. of a freshly passed, 18-hour blood broth culture killed a mouse weighing 18 to 20 grams within 24 to 48 hours. Varying amounts of culture, $10^{-8}, 10^{-7}, 10^{-6}(1,10$ and 1,000 M.L.D.), were employed in the tests with Type I, and $10^{-6}$ to $10^{-8} \mathrm{ml} .(1,10,100,1,000,10,000$ and 100,000 M.L.D.), with Type III pneumococci. Dilutions were so adjusted that $0.5 \mathrm{ml}$. of each contained the desired amount of culture. The culture and serum were injected intraperitoneally, the serum immediately before the culture (within an interval of a few seconds).

The dose of serum for each mouse was $0.5 \mathrm{ml}$., injected intraperitoneally.

Surviving mice were discharged at the end of 7 days.

Absorption tests were conducted in the following manner: Freshly passed cultures were grown for 4 hours at $37^{\circ} \mathrm{C}$. The cultures were killed by heating at $55^{\circ} \mathrm{C}$. for 30 minutes, centrifuged at high speed for one hour, and the "supernatant" discarded. The serum was added to the cells in the proportion of $1 \mathrm{ml}$. of serum to the sediment of $2 \mathrm{ml}$. of culture. The serum and cells were well mixed and placed in a water bath at $45^{\circ} \mathrm{C}$. for one hour. Serum without cells was similarly kept in a water bath at $45^{\circ} \mathrm{C}$. for one hour and used as controls. Then 0.1 per cent formalin was added to the mixtures and the tubes placed in an icebox overnight. The serum and cell suspension was then centrifuged and the clear serum withdrawn. Absorbed sera were not used in the protection tests before sterility tests showed complete absence of live organisms. Absorbed sera, without culture, were also injected into mice as additional controls.

\section{RESULTS OF THE MOUSE PROTECTION TESTS}

\section{Protection against pneumococcus Type I}

Of the 12 normal human adult sera tested against pneumococcus Type I only 2 gave protection when used without sulfapyridine. These sera saved 11 of 12 mice infected with Type I organisms. None of the remaining 10 sera protected the animals to any appreciable extent when administered alone. However, all sera protected the animals to a high degree (from 66 to 100 per cent of the animals tested) when given with sulfapyridine, while the mice receiving sulfapyridine alone either all succumbed to the infection or only one out of 6 mice recovered.

None of the normal infants' sera employed in the tests gave any appreciable protection, either alone or with sulfapyridine, against Type I pneumococcus.

Normal mouse, guinea pig, rabbit, and rat sera did not protect the mice against Type I pneumo- 
SOPHIE SPICER

TABLE I

Protective action of normal human and animal sera on white mice infected with $T y$ pe I pneumococcus when treated with sulfapyridine

\begin{tabular}{|c|c|c|c|c|c|c|c|c|c|c|c|c|}
\hline \multirow{2}{*}{ Source of serum } & \multicolumn{4}{|c|}{ Serum $0.5 \mathrm{ml}$. alone } & \multicolumn{4}{|c|}{$\begin{array}{l}\text { Sulfapyridine alone } \\
1 \text { per cent in food for } 2 \text { days }\end{array}$} & \multicolumn{4}{|c|}{ Serum and sulfapyridine } \\
\hline & $\begin{array}{c}\text { Number } \\
\text { mice } \\
\text { tested }\end{array}$ & $\mid \begin{array}{l}\text { Number } \\
\text { mice re- } \\
\text { covered }\end{array}$ & $\begin{array}{c}\text { Per cent } \\
\text { of mice } \\
\text { recovered }\end{array}$ & $\begin{array}{c}\text { Average } \\
\text { days } \\
\text { survived }\end{array}$ & $\begin{array}{c}\text { Number } \\
\text { mice } \\
\text { tested }\end{array}$ & $\begin{array}{l}\text { Number } \\
\text { mice re- } \\
\text { covered }\end{array}$ & \begin{tabular}{|c|} 
Per cent \\
of mice \\
recovered
\end{tabular} & $\begin{array}{l}\text { Average } \\
\text { days } \\
\text { survived }\end{array}$ & $\begin{array}{c}\text { Number } \\
\text { mice } \\
\text { tested }\end{array}$ & $\begin{array}{l}\text { Number } \\
\text { mice re- } \\
\text { covered }\end{array}$ & $\left|\begin{array}{c}\text { Per cent } \\
\text { of mice } \\
\text { recovered }\end{array}\right|$ & $\begin{array}{l}\text { Average } \\
\text { days } \\
\text { survived }\end{array}$ \\
\hline $\begin{array}{l}\text { Adult human } \\
10 \text { samples } \\
\text { (None pro- } \\
\text { tective when }\end{array}$ & 60 & 4 & 6.6 & 2.7 & 60 & 3 & 5 & 3.1 & 60 & 46 & 77 & 6 \\
\hline $\begin{array}{c}\text { Adult human } 2 \\
\text { samples (Pro- } \\
\text { tective when } \\
\text { used alone) }\end{array}$ & 12 & 11 & 91.6 & 5.9 & 12 & 1 & 8.3 & 3.1 & 12 & 12 & 100 & 7 \\
\hline $\begin{array}{l}\text { Infant human } \\
10 \text { samples } \\
4 \text { individual }\end{array}$ & 30 & 1 & 3.3 & 1.9 & 36 & 1 & 2.7 & 2.5 & 31 & 4 & 12.9 & 3.3 \\
\hline $\begin{array}{l}6 \text { pooled } \\
\text { Mice } \\
66 \text { pooled }\end{array}$ & 6 & 0 & 0 & 2 & 6 & $\mathbf{0}$ & $\mathbf{0}$ & 2.3 & 6 & 1 & 16.6 & 4.1 \\
\hline Guinea pigs & 6 & $\mathbf{0}$ & 0 & 1.6 & 6 & 0 & $\mathbf{0}$ & 3.3 & 6 & 1 & 16.6 & 3.3 \\
\hline Rabbit & 6 & $\mathbf{0}$ & 0 & 1.5 & 6 & 0 & $\mathbf{0}$ & 2.5 & 6 & $\mathbf{0}$ & $\mathbf{0}$ & 2.8 \\
\hline Dog & 6 & 4 & 66.6 & 5.5 & 6 & 1 & 16.6 & 3.6 & 6 & 6 & 100 & 7 \\
\hline $\begin{array}{l}\text { one } \\
\text { Rats } \\
15 \text { pooled }\end{array}$ & 6 & $\mathbf{0}$ & $\mathbf{0}$ & 2 & 6 & $\mathbf{0}$ & $\mathbf{0}$ & 2 & 6 & $\mathbf{0}$ & $\mathbf{0}$ & 2.3 \\
\hline
\end{tabular}

coccus when used alone or with sulfapyridine. Normal dog serum, however, gave about 66 per cent protection to the mice when used alone, and 100 per cent protection when used with sulfapyridine.

Table I is a summation of the mouse protection tests, with the various normal sera, against Type I pneumococcus.

As seen from Table II, fresh, unheated human

TABLE II

Mouse protection test with normal human adult serum $(757 \mathrm{~A})$ used fresh and heated with and without sulfapyridine against Type I preumococcus

\begin{tabular}{|c|c|c|c|c|c|}
\hline Treatment & $\begin{array}{l}\text { Number of } \\
\text { M.L.D. of } \\
\text { culture }\end{array}$ & $\begin{array}{l}\text { Num- } \\
\text { ber of } \\
\text { mice } \\
\text { in- } \\
\text { fected }\end{array}$ & $\begin{array}{c}\text { Num- } \\
\text { ber of } \\
\text { mice } \\
\text { recov- } \\
\text { ered }\end{array}$ & $\begin{array}{l}\text { Per } \\
\text { cent } \\
\text { re- } \\
\text { cov- } \\
\text { ered }\end{array}$ & $\begin{array}{c}\text { Aver- } \\
\text { age } \\
\text { days } \\
\text { sur- } \\
\text { vived }\end{array}$ \\
\hline $\begin{array}{l}\text { Fresh serum alone } \\
\text { Fresh serum with } \\
\text { sulfapyridine }\end{array}$ & $\begin{array}{l}1,10,1,000 \\
1,10,1,000\end{array}$ & $\begin{array}{l}6 \\
6\end{array}$ & $\begin{array}{l}3 \\
6\end{array}$ & $\begin{array}{r}50 \\
100\end{array}$ & 4.5 \\
\hline Heated serum at $56^{\circ}$ & $1,10,1,000$ & 6 & 0 & 0 & 2 \\
\hline $\begin{array}{l}\text { Heated serum at } 56^{\circ} \\
\text { C. with sulfa- } \\
\text { pyridine }\end{array}$ & $1,10,1,000$ & 6 & 4 & 83 & 5.3 \\
\hline $\begin{array}{l}\text { Sulfapyridine alone } \\
\text { Culture controls }\end{array}$ & $\begin{array}{l}1,10,1,000 \\
1,10,1,000\end{array}$ & $\begin{array}{l}6 \\
6\end{array}$ & $\begin{array}{l}\mathbf{0} \\
\mathbf{0}\end{array}$ & $\begin{array}{l}\mathbf{0} \\
\mathbf{0}\end{array}$ & $\begin{array}{l}2.5 \\
1.8\end{array}$ \\
\hline
\end{tabular}

* Heated for 30 minutes. adult serum (24 hours after bleeding) gave 50 per cent protection, but the same serum heated for 30 minutes at $56^{\circ} \mathrm{C}$. gave no protection when used without sulfapyridine. The heated serum, when given with sulfapyridine, protected the mice to a lesser extent than the unheated, fresh serum given with sulfapyridine. One other serum tested, fresh and heated, gave similar results.

None of the absorbed sera gave any protection when absorbed with homologous cultures, whether used alone or with sulfapyridine. Absorption with heterologous cultures removed most of the protective substances, but not all, since some protection still resulted from these sera, even when very large doses of cultures were used for absorption. Absorption with kaolin had no effect on the sera. Nor did the absorbed sera, when injected without culture, have any effect on the mice. Table III represents a test with absorbed sera.

\section{Protection against pneumococcus Type III}

No direct parallelism was noted in the action of the sera when tested against Type I and Type III pneumococci. Whereas the great majority of 
TABLE III

Mouse protection test with normal human adult serum $(757 \mathrm{~A})$ absorbed with Type I and Type II pneumococcus cells against Type $I$ and Type II pneumococcus cultures

\begin{tabular}{|c|c|c|c|c|}
\hline \multirow{3}{*}{ Material injected } & \multicolumn{4}{|c|}{ 1, 10, 1,000 M.L.D. } \\
\hline & \multicolumn{2}{|c|}{ Type I culture } & \multicolumn{2}{|c|}{ Type II culture } \\
\hline & $\begin{array}{l}\text { Number } \\
\text { recovered }\end{array}$ & $\begin{array}{c}\text { Number } \\
\text { died }\end{array}$ & $\begin{array}{l}\text { Number } \\
\text { recovered }\end{array}$ & $\begin{array}{c}\text { Number } \\
\text { died }\end{array}$ \\
\hline $\begin{array}{l}\text { Serum absorbed with } \\
\text { Type I cells alone }\end{array}$ & 0 & 6 & $\mathbf{0}$ & 6 \\
\hline $\begin{array}{l}\text { Serum absorbed with } \\
\text { Type I cells with } \\
\text { sulfapyridine }\end{array}$ & 0 & 6 & 2 & 4 \\
\hline $\begin{array}{c}\text { Serum absorbed with } \\
\text { Type II cells alone }\end{array}$ & 0 & 6 & $\mathbf{0}$ & 6 \\
\hline $\begin{array}{l}\text { Serum absorbed with } \\
\text { Type II cells with } \\
\text { sulfapyridine }\end{array}$ & 1 & 5 & $\mathbf{0}$ & 6 \\
\hline $\begin{array}{l}\text { Unabsorbed serum } \\
\text { alone }\end{array}$ & 3 & 3 & 3 & 3 \\
\hline $\begin{array}{l}\text { Unabsorbed serum } \\
\text { with sulfapyridine }\end{array}$ & 6 & 0 & 5 & 1 \\
\hline $\begin{array}{l}\text { Sulfapyridine alone } \\
\text { Culture controls }\end{array}$ & $\begin{array}{l}\mathbf{0} \\
\mathbf{0}\end{array}$ & $\begin{array}{l}6 \\
6\end{array}$ & $\begin{array}{l}\mathbf{0} \\
\mathbf{0}\end{array}$ & $\begin{array}{l}6 \\
6\end{array}$ \\
\hline
\end{tabular}

the normal adult human sera did not show any demonstrable protective ability against Type I organisms when used alone, and showed a definite increase in survival rate when used with sulfapyridine, such sera protected mice against Type III strains and failed to increase the survival rate of

TABLE IV

Mouse protection test with normal human adult serum (AA 107) used fresh and heated with and without sulfapyridine against Type III pneumococcus

\begin{tabular}{c|c|c|c|c|c}
\hline \hline Treatment & $\begin{array}{c}\text { Number of } \\
\text { M.L.D. of } \\
\text { culture }\end{array}$ & $\begin{array}{c}\text { Num- } \\
\text { ber of } \\
\text { mice } \\
\text { in- } \\
\text { fected }\end{array}$ & $\begin{array}{c}\text { Num- } \\
\text { ber of } \\
\text { mice } \\
\text { recov- } \\
\text { ered }\end{array}$ & $\begin{array}{c}\text { Per } \\
\text { cent } \\
\text { re- } \\
\text { cov- } \\
\text { ered }\end{array}$ & $\begin{array}{c}\text { Aver- } \\
\text { age } \\
\text { days } \\
\text { sur- } \\
\text { vived }\end{array}$ \\
\hline $\begin{array}{c}\text { Fresh serum } \\
\text { alone }\end{array}$ & $\begin{array}{c}1,10,100,1,000, \\
10,000,100,000\end{array}$ & 12 & 1 & 8.4 & 2.6 \\
$\begin{array}{c}\text { Fresh serum with } \\
\text { sulfapyridine }\end{array}$ & $\begin{array}{c}1,10,100,1,000, \\
10,000,100,000\end{array}$ & 12 & 3 & 25 & 4.7 \\
$\begin{array}{c}\text { Heated serum at } \\
56^{\circ} \text { C. alone }\end{array}$ & $\begin{array}{c}1,10,100,1,000, \\
10,000,100,000\end{array}$ & 12 & 2 & 16.6 & 2.8 \\
$\begin{array}{c}\text { Heated serum at } \\
56^{\circ} \text { C. with } \\
\text { sulfapyridine }\end{array}$ & $\begin{array}{c}1,10,100,1,000, \\
10,000,100,000\end{array}$ & 12 & 6 & 50 & 5.7 \\
$\begin{array}{c}\text { Heated serum at } \\
60^{\circ} \text { C. alone }\end{array}$ & $\begin{array}{c}1,10,100,1,000, \\
10,000,100,000\end{array}$ & 12 & 4 & 33.3 & 3.5 \\
$\begin{array}{c}\text { Heated serum at } \\
60^{\circ} \text { C. with } \\
\text { sulfapyridine }\end{array}$ & $\begin{array}{c}1,10,100,1,000, \\
10,000,100,000\end{array}$ & 12 & 8 & 66.6 & 5.8 \\
$\begin{array}{c}\text { Sulfapyridine } \\
\text { alone }\end{array}$ & $\begin{array}{c}1,10,100,1,000, \\
10,000,100,000\end{array}$ & 12 & 10 & 83 & 6.6 \\
$\begin{array}{c}\text { Culture controls } \\
1,10,100\end{array}$ & 6 & 0 & 0 & 2 \\
\hline
\end{tabular}

* Heated for 30 minutes.

$\dagger$ Heated for one hour. the sulfapyridine-treated mice, producing instead a decrease in the protective action of the sulfapyridine. There was a definite inhibition in the protective activity when the sera were used with Type III organisms. This inhibitory action was decreased but not entirely destroyed by heating. Table IV represents a typical experiment showing this inhibitory action.

\section{Protection against other types}

One normal human adult serum was tested against Types II, IV, V, VI, IX and XVIII, with and without sulfapyridine. It gave 100 per cent protection both when used alone and with sulfapyridine, against 1,000 M.L.D.'s of virulent organisms. Since no end point of protection was obtained with the amounts of culture used, it was impossible to determine whether the serum with sulfapyridine increased the survival rate, when tested against these types.

\section{DISCUSSION}

Although pneumococcidal antibodies are encountered in the blood of normal human adults with great frequency ( 1 to 11 ), mouse protective activity of normal human sera is usually found to be low, or not demonstrable at all (8). With the aid of sulfapyridine, used in amounts so small that by itself it did not give any protection, we were able to demonstrate protective antibodies against Type I pneumococci in all the normal human adult sera tested, although 10 of the 12 sera examined did not show any protection when used alone. On the other hand, when sera from normal human infants, aged $4 \frac{1}{2}$ to 7 months, were examined, no protection was apparent, whether the sera were used alone or with sulfapyridine. These results are in agreement with the work of others (12 to 14 ), who found that the pneumococcidal antibodies in very young infants, obtained through the passive transfer from the mother, are exhausted at the end of 5 to 6 weeks, and reappear in the blood of the child when about a year old.

Robertson and Sia (11) as well as others (9, 15 to 17$)$ found that the common laboratory animals, exhibiting a high degree of resistance to pneumococci, such as the horse, sheep, dog, cat 
and pig, possess natural pneumococcus immune substances, whereas the guinea pig and the rabbit, which are not resistant, do not demonstrate immune substances. In our present work we were able to demonstrate mouse protective antibodies in the resistant dog, but not in the non-resistant rabbit, guinea pig, rat or mouse, even with the aid of sulfapyridine.

Absorption tests showed complete absorption of the antibodies from the sera by the homologous cultures, as evidenced by the failure of the absorbed sera to protect against the homologous type when used with sulfapyridine. Heterologous cultures, on the other hand, removed most, but not all, of the protective bodies, since some protection, although low, resulted with some of the absorbed sera. It is possible that protective activity in "naturally" resistant individuals is due to the presence of type-specific, as well as speciesspecific, antibodies in their blood.

Heating the sera resulted in reduction of the protective titer against Type I pneumococci, whether the sera were used alone or with sulfapyridine. Whether this is the result of the somewhat heat-labile character of the protective antibodies, or whether the presence of complement in the fresh serum enhanced the protective activity, is difficult to tell. Robertson and Sia (11) who did comparative opsonic tests on heated and unheated animal sera found that the heated sera lost much of their opsonic potency but still retained varying degrees of this property.

The experiments conducted with the normal human adult sera against Type I and Type III pneumococci brought out certain dissimilarities in the action of the sera with the two types. Although the sera tested exhibited a high antibody content against Type III strains, the presence of some inhibiting mechanisms was apparent from the results of the experiments. The nature of this inhibiting action has not been determined but its existence was definitely shown by the following findings: Whereas sera tested against Type I organisms exhibited higher protection in the fresh state, both used alone and with sulfapyridine, this was not the case with Type III. Paradoxically enough, the heating enhanced the protective activity. Parallel tests with fresh sera and with the same sera heated at $56^{\circ} \mathrm{C}$. for 30 minutes, and at $60^{\circ} \mathrm{C}$. for one hour, showed an increase in protective titer in the heated sera which varied directly with the degree of temperature and time of exposure to the heat. This inhibiting action was manifested when sulfapyridine-susceptible strains, as well as relatively resistant strains, were used. It was particularly well demonstrated with a highly susceptible strain, as can be seen from Table IV. The inhibiting action was not entirely destroyed by heating the sera. The highest protection resulted from sulfapyridine alone, next highest with sulfapyridine and serum heated at $60^{\circ} \mathrm{C}$. for one hour, next, sulfapyridine with serum heated at $56^{\circ} \mathrm{C}$. for 30 minutes, and least with sulfapyridine plus unheated serum.

That this inhibitory action was not due to any toxicity of the sera for the mice was shown by the absence of any effect on the mice injected with large amounts of fresh serum without culture. At the present time we can think of only two possibilities to account for this peculiar action; either the contact of the organisms with certain substances in the sera forms a complex which inhibits the sulfapyridine action, or certain Type III strains simply grow very rapidly in the sera and thus sulfapyridine protection is reduced.

\section{SUM MARY}

1. Using mice fed a diet containing 1 per cent sulfapyridine as test animals, blood sera from other mice, rats, guinea pigs, rabbits, dogs and infant humans and adult humans were examined to find the relative activity of these sera in protecting against pneumococcus infection.

2. The sera of dogs and adult humans increased the survival rate of sulfapyridine-treated mice, when tested against Type I pneumococci. The sera of mice, rats, guinea pigs, rabbits and human infants did not increase the survival rate of sulfapyridine-treated mice against this type.

3. Human adult sera protected mice against small doses of Type III pneumococci but diminished, instead of enhancing, the survival rate of sulfapyridine-treated mice infected with Type III pneumococci.

4. Absorption with homologous pneumococcus cultures destroyed the protective activity completely. Absorption with heterologous cultures left a smaller or larger fraction of protective ac- 
tivity, even when very large doses of culture were used for absorption.

The author gratefully acknowledges the technical assistance of Miss Sarah Eidlin.

\section{BIBLIOGRAPHY}

1. Sutliff, W. D., and Rhoades, D. R., The pneumococcidal power of whole blood. I. Description of method. Results in individuals with no history of lobar pneumonia. J. Clin. Invest., 1930, 9, 43.

2. Sutliff, W. D., and Rhoades, D. R., The pneumococcidal power of whole blood. II. Estimations in lobar pneumonia. J. Clin. Invest., 1930, 9, 55.

3. Finland, M., and Sutliff, W. D., Specific antibody response of human subjects to intracutaneous injection of pneumococcus products. J. Exper. Med., 1932, 55, 853.

4. Finland, M., and Sutliff, W. D., Immunity reactions of human subjects to strains of pneumococci other than Types I, II and III. J. Exper. Med., 1933, 57, 95.

5. Robertson, O. H., and Sia, R. H. P., Studies on pneumococcus growth inhibition. II. A method for demonstrating the growth-inhibitory and bactericidal action on normal serum-leucocyte mixtures. J. Exper. Med., 1924, 39, 219.

6. Robertson, O. H., and Cornwell, M. A., Study of resistance of normal human beings to recently isolated strains of pathogenic pneumococci. J. Exper. Med., 1930, 52, 267.

7. Robertson, O. H., Terrell, E. E., Graeser, J. B., and Cornwell, M. A., Relation of natural humoral antipneumococcal immunity to the inception of lobar pneumonia. J. Exper. Med., 1930, 52, 421.
8. Graeser, J. B., and Harrison, M. C., Changes in the titer of antipneumococcal humoral immunity in adult human beings. J. Exper. Med., 1933, 58, 245.

9. Heist, G. D., Solis-Cohen, S., and Solis-Cohen, M., The bactericidal action of whole blood with a new technique for its determination. J. Immunol., 1918, 3, 261.

10. Robertson, O. H., Graeser, J. B., and Coggeshall, L. T., and Harrison, M. A., The relation of circulating antipneumococcal immune substances to the course of pneumonia. I. Natural immune substances. J. Clin. Invest., 1934, 13, 621.

11. Robertson, O. H., and Sia, R. H. P., Studies on pneumococcus growth inhibition. VII. The relation of opsonins to natural resistance against pneumococcus infection. J. Exper. Med., 1927, 46, 239.

12. Sutliff, W. D., and Finland, M., Antipneumococcic immunity reactions in individuals of different ages. J. Exper. Med., 1932, 55, 837.

13. Sutliff, W. D., and Davies, J. A. V., A study of the origin of the naturally occurring immune bodies for pneumococci in infants. J. Immunol., 1937, 32, 43.

14. Burhans, C. W., and Gerstenberger, H. J., The protective power of infants' and maternal serum against pneumococci. Am. J. Dis. Child., 1924, 28, 415.

15. Bull, C. G., Immunity factors in pneumococcus infection in the dog. J. Exper. Med., 1916, 24, 7.

16. Bull, C. G., and McKee, C. M., Antipneumococcus protective substances in normal chicken serum. Am. J. Hyg., 1921, 1, 284.

17. Terrell, E. E., Robertson, O. H., and Coggeshall, L. T., Experimental pneumococcus lobar pneumonia in the dog. I. Method of production and course of the disease. J. Clin. Invest., 1933, 12, 393. 